CARr, J. G. (1953). J. gen. Microbiol. 8, 427-433.

\title{
The Association of Haemin with the Fowl Cancer Viruses
}

\author{
BY J. G. CARR \\ British Empire Cancer Campaign Unit, Poultry Research Centre, \\ Edinburgh
}

SUMMARY: Haemin was found in all specimens of purified preparations of Rous I, Duran-Reynals B, D and V, Fujinami, and MH2 viruses, and also in macromolecular preparations from non-filterable fowl sarcomas and normal fowl tissues. The amounts were not constant in different batches of Rous I, and it was shown that this virus would strongly adsorb pure haemin from solution. It is suggested that most, probably all, of the haemin encountered in these preparations was derived from the host blood. Adsorbed haemin had no effect on the oxidative destruction of the virus, but slightly altered its physical properties.

It was noticed that preparations of fowl sarcoma viruses made by fractional centrifugation of tumour extracts and enzyme digestion (Amies \& Carr, 1939; Carr \& Harris, 1951) gave slightly cream-coloured suspensions and yellowbrown pellets when centrifuged, in contrast to most other viruses, e.g. vaccinia, concentrates of which are a dead chalky white. It was thought that the colour of the former might indicate the presence of an enzyme, a suspicion reinforced by the fact that these viruses are the only ones that are destroyed so rapidly by oxidation (Mueller, 1928; Gye \& Purdy, 1930) that all but the most rapid experiments must be done in the presence of an oxidase inhibitor. The present work was undertaken to study this coloured material.

\section{EXPERIMENTAL}

Coloured preparations were obtained from all the fowl tumour virus preparations studied, that is: Rous I, Duran-Reynals B, D and V, Des Ligneris, Fujinami and MH2. The details of the methods of concentrating varied somewhat (see Amies \& Carr, 1939; Carr \& Harris, 1951). The 'normal particles' or macromolecular preparations which result by applying similar methods to normal fowl tissues or to two chemically induced and nonfilterable fowl sarcomas (obtained by courtesy of J. McIntosh \& F. R. Selbie, and P. R. Peacock) appeared to be colourless. The colour of different batches of virus varied, and records for the two most closely studied, Rous I and DuranReynals $\mathrm{D}$, showed that there was a strong correlation of depth of colour with virus activity, those tumours which yielded most virus per gram of tissue gave preparations of the deepest colour, while inactive or almost inactive preparations were almost white. This, together with the finding for non-virus particles, seemed to confirm the idea that the coloured material was an integral part of the infective virus. Chemical and biochemical studies undertaken on the basis of this idea proved abortive and need not be described. The approach next described was more informative. 
In the subsequent work, the following standard procedures were used.

Virus preparations were always made by treating an aqueous $10 \%(\mathrm{w} / \mathrm{v})$ extract of macerated tumour with a hyaluronidase preparation to decrease the high viscosity, clarifying on a Servall angle centrifuge at 4000 r.p.m. for $15 \mathrm{~min}$., and centrifuging the supernatant for $40 \mathrm{~min}$. at 12,000 r.p.m. The pellet was resuspended and clarified at $1000 \mathrm{~g}$ for $10 \mathrm{~min}$. on a horizontal centrifuge. If then treated with crystalline trypsin and redeposited at high speed, the resuspended pellet is referred to as 'purified' virus.

The benzidine test was made with a saturated solution of freshly recrystallized benzidine in acetic acid followed by the addition of ' 10 volume' hydrogen peroxide solution.

Buffers used were veronal $(0 \cdot 1 \mathrm{~m}$-veronal $+0 \cdot 1 \mathrm{M}-\mathrm{HCl})$ and glycine $(0 \cdot 1 \mathrm{M}$ glycine in $0 \cdot 1 \mathrm{M}-\mathrm{NaCl}+0 \cdot 1 \mathrm{M}-\mathrm{NaOH}$ ).

Infectivity titrations were made by inoculating $0.2 \mathrm{ml}$. volumes of decimal dilutions of virus suspension into young chicks (Carr \& Harris, 1951).

It will be convenient in the subsequent sections to use the term haemin for the chemically pure compound when used, and haematin for natural material which gave a benzidine test but was not further characterized.

\section{Presence of haematin on particles}

Most of the virus-induced fowl tumours are very rapidly growing and malignant in susceptible hosts; the tumour tissue contains many haemorrhagic spots and often large clots of blood in various stages of destruction. The latter are formed presumably when the vascular system fails to extend as rapidly as the tumour tissue in which it is embedded and is thereby ruptured. The presence of old blood implies the presence of haematin which is known to adsorb very strongly to almost any protein. It was therefore suspected that a part of the colour of the virus preparations might be due to such adventitious haematin. A preparation of 'purified' Rous I virus gave a strongly positive reaction with the benzidine test. Centrifugation experiments indicated that the material reacting with benzidine resided solely in the particles; the supernatants after deposition of the particles were inactive to the reagent. Similar tests showed that preparations of Duran-Reynals D, Fujinami and MH2 virus also contained haematin, as did particles derived from the non-filterable GRCH/15 sarcoma of Peacock, and from normal spleen, thymus, heart, muscle, or bursa of Fabricius. Though the benzidine test is not a quantitative one, the reactions of the latter preparations were clearly very much weaker than those of the virus preparations. It was concluded that these preparations too contained haematin in small quantities, although insufficient to give an obvious brown colour to the particles. The apparent correlation of the colour of the virus preparations with their activities seems therefore to be merely a reflexion of the growth-rates of the tumours from which they were derived, for most virus is harvested from rapidly growing tumours which are also usually the most haemorrhagic (Carr, 1953). The GRCH/15 sarcoma and the normal tissues contain by comparison relatively little blood, and no old clots. 


\section{Adsorption of haemin}

Attempts to remove haematin from the virus preparations and yet leave them infective were unsuccessful. Centrifugation at various $\mathrm{pH}$ values in veronal

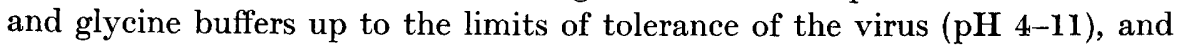
extraction of freeze-dried virus or tumour with petrol ether, ether, hexane, benzene, chloroform or dioxan, failed to remove the colour. Paper-strip chromatography with various aqueous salt solutions as the moving phase, or paper strip electrophoresis at $\mathrm{pH}$ values of 5,7 or 9 , all failed to separate the haematin and the protein components. More drastic methods destroyed the virus, and even then the haematin remained attached to any protein or denatured protein matter still left, and did not go into solution.

On the other hand, virus preparations readily adsorbed much more haemin. A preparation of Rous 1 virus from $40 \mathrm{~g}$. tumour was resuspended in $20 \mathrm{ml}$. Lemco broth $+20 \mathrm{ml}$. water, and two samples of $12.5 \mathrm{ml}$. were taken. To one sample an equal volume of $0 \cdot 1 \mathrm{M}$-veronal was added, and to the other an equal volume of $0 \cdot 1 \mathrm{M}$-veronal saturated with haemin hydrochloride. The preparations were deposited at $12,000 \mathrm{~g}$ in the angle centrifuge; the haemin-treated material gave a pellet which was black. The pellets were resuspended in $12.5 \mathrm{ml}$. Lemco broth (i.e. $1 \mathrm{ml}=1 \mathrm{~g}$. tumour), and on titrating in young chicks they were found to be equally potent and equal in potency to the original preparation; they gave tumours at a dilution corresponding to $0 \cdot 2 \times 10^{-4} \mathrm{~g}$. of tumour. This type of experiment was done seven times with variations in the 'purity' of the virus (i.e. inserting a stage of tryptic digestion) and in the number of washings the pellets received after staining with haemin. Always the infectivity was unaltered by the adsorption of haemin, and the pellets always remained black.

Haemin adsorbed on Rous 1 virus in this way was as firmly attached as the natural colour, and was not to be removed by any of the methods that had been tried for the removal of the haematin. It did, however, appear slightly to modify the physical behaviour of the virus preparations. The haemin-stained material seemed to yield a more sticky and coherent pellet after centrifugation, and resuspension to give dispersed particles was noticeably more difficult. Since this phenomenon might have affected some of the methods used to 'purify' various virus preparations, it was studied in more detail.

\section{Effect of haemin on physical properties}

A preparation of 'purified' Rous I virus was made and divided into two parts, one of which was stained with haemin in the manner previously described. Each portion was separately clarified at $1000 \mathrm{~g}$ on the horizontal centrifuge, and the two portions then united. This material was submitted to three cycles of alternate fast and slow centrifugation, after the manner usually recommended for the purification of viruses. It was noted that at each deposition the stained material tended to collect at the bottom of the pellet, probably because of the extra specific gravity conferred by the iron of the haemin molecules. Furthermore, since this material resuspended less 
readily, it was possible to stop resuspension at a stage when the unstained material was more dispersed than the stained, and on clarification at $1000 \mathrm{~g}$ the deposit contained more of the haemin. Thus by partial separation at each stage, three cycles were enough to separate the two fractions almost completely. Such coloured material is often discarded as 'impurity' by such cyclic processing in the purification of viruses by fractional centrifugation. In the present instance a loss of $50 \%$ of active virus resulted from the attempt to remove a fraction of a percentage of harmless haemin, and that incompletely. This suggests that such 'purification' is wasteful and unnecessary in many cases.

\section{Effect of haemin on oxidative destruction of virus activity}

Though haemin had thus been shown to have no immediate effect upon the virus, it remained possible that its presence might affect the stability of the virus to oxidation. There does not seem to be any evidence that the destruction by oxidation is due to an enzyme contained in or adsorbed by the virus; oxidative destruction has been shown only in tumour extracts, and it is possible that any enzymic reaction is due to the tissue extract itself. In any case adsorbed haemin (which may act like catalase) might modify the result, either protectively by destroying peroxide or destructively by liberating 'active' oxygen at the surface of the virus particle. The following experiments were therefore carried out.

In each experiment, a preparation of 'purified' Rous 1 virus was made and divided into two parts, one of which was stained with haemin as described above, washed by depositing the virus once more from the suspension, and resuspended in the medium required. The unstained portion was treated in the same way except that haemin was not added. The two parts were titrated and always found to have equal amounts of active virus before further treatment.

Destruction at $37^{\circ}$. The stained and unstained preparations were resuspended in Lemco broth to concentrations such that $1 \mathrm{ml}$. $\equiv 2$ g. tumour. Two samples of $5 \mathrm{ml}$. were placed in $2 \mathrm{oz}$. McCartney bottles; to one set was added $5 \mathrm{ml}$. of Lemco broth and to the other $5 \mathrm{ml}$. of the original tissue extract from which the virus had been deposited, thus reconstituting the clarified tumour extract diluted with Lemco broth. All bottles were loosely stoppered and incubated for $20 \mathrm{hr}$. at $37^{\circ}$. At the end of that time they were tested and found to be bacteriologically sterile, and the activity had fallen from $10^{4}$ tumour-inducing particles $/ \mathrm{ml}$. to zero in all four bottles. Inactivation of 'purified' virus therefore occurred independently of the presence of the tissue extract, and the presence of haemin did not affect this in either case.

Protection by $\mathrm{HCN}$ at $37^{\circ}$. The stained and unstained preparations were resuspended in the extract from which the virus had been deposited, and three samples of $5 \mathrm{ml}$. of each placed in McCartney bottles. To each was added respectively $1 \mathrm{ml}$. of $\mathrm{HCN}$ at concentrations to give final amounts of $1 / 10,000$, $1 / 20,000$ and $1 / 40,000$, and then to each bottle a solution of $400 \mathrm{I} . \mathrm{U}$. penicillin in $0.2 \mathrm{ml}$. After incubation at $37^{\circ}$ for $20 \mathrm{hr}$. with loose stoppers, no loss of virus activity was found in any bottle, and all were bacteriologically sterile. 
Destruction at $0^{\circ}$ for $5 \frac{1}{2}$ and $30 \mathrm{hr}$., and at $37^{\circ}$ for $5 \frac{1}{2} \mathrm{hr}$. The stained and unstained preparations were resuspended in Lemco broth at a concentration such that $1 \mathrm{ml}$. $\equiv 2 \mathrm{~g}$. tumour and two $5 \mathrm{ml}$. samples of each placed in loosely stoppered McCartney bottles. One set was incubated at $37^{\circ}$, the other set placed in a refrigerator at $0^{\circ}$. Each was titrated after $5 \frac{1}{2} \mathrm{hr}$. when an activity of $c .10 \%$ of the original was found in the specimens incubated at $37^{\circ}$, while those incubated at $0^{\circ}$ were substantially unaltered. The latter were tested again after a total of $30 \mathrm{hr}$. at $0^{\circ}$, when only a slight fall in activity was shown by both the stained and unstained specimens.

Destruction at room temperature (c. $14^{\circ}$ ). Stained and unstained specimens were resuspended in Lemco broth containing 400 I.U. penicillin at a concentration of $1 \mathrm{ml} . \equiv 2 \mathrm{~g}$. tumour, and left in McCartney bottles on the bench. After $20 \mathrm{hr}$. a $90 \%$ fall in activity was found to have occurred in each bottle, and a further fall to about $1 \%$ of the original activity value was found after a further $20 \mathrm{hr}$. for each specimen. Under all conditions tested, therefore, the stained and unstained preparations were equally sensitive to oxidative destruction, and equally protected by $\mathrm{HCN}$.

\section{DISCUSSION}

Since it has been shown that the fowl virus preparations and macromolecular preparations from normal and malignant tissues give a benzidine reaction like haematin, and that haemin will strongly adsorb upon such virus preparations, it is reasonable to conclude that much of the haematin on the particles is derived from the host blood. The correlation of depth of colour of the particles with the amount of blood in the tissue supports this. The absence of other pigment in the particles has not been proved. Even if blood-derived haematin could be eliminated (e.g. by using tissue culture material), the tumour cells themselves would contain haem pigments, e.g. cytochrome, so that preparation of virus free from haematin is perhaps impossible, even if the pigment is purely adventitious.

Since haematin has a catalase-like activity, the reports that catalase is associated with these fowl-tumour viruses require reconsideration. Catalase activity has been reported for Rous 1 by Stern \& Duran-Reynals (1939), and for erythroleukaemia virus by Stern \& Kirschbaum (1939), though these workers were uncertain whether the activity was due to the viruses themselves or to an 'associated substance'. The present work suggests that much, perhaps all, of the catalase activity in their virus preparations could have been due to adsorbed haematin, and that no catalase proper was involved. Catalase activity was reported for vaccinia preparations by Macfarlane \& Salaman (1940); Hoagland, Ward, Smadel \& Rivers (1942) pointed out that catalase was strongly adsorbed by vaccinia from a dilute solution of the enzyme. Neither group of workers seems to have considered the possibility of haematin as a possible contaminant of their vaccinia virus preparations. It is unlikely that a decision as to whether the catalase activity is due to an enzyme or to haemin can be reached by determining the catalase activity of virus preparations. Though the activity of haemin is much weaker than most catalase 
enzymes on a molecular basis (Kreke, Bartlett \& Smalt, 1945), this may not apply when the haemin is associated with a protein, for at least one haemprotein complex is catalase itself. Even if this complication be ignored, there is room for relatively many more haem molecules than catalase molecules on the surface of a virus particle. In addition, it is unlikely that a catalase molecule could penetrate inside a virus particle, while the depth of colour of the haemin-stained virus preparations indicates that the haemin molecule is probably contained inside as well as outside the particle. The much greater quantity of haemin that a virus particle can carry might compensate for its decreased activity. The presence of haematin implies the presence of iron, yet investigations on vaccinia virus preparations (Hoagland et al. 1940) and normal macromolecular protein (Claude, 1941) indicate the presence of copper. It is, of course, possible that iron-containing particles were discarded during purification by fractional centrifugalization, as was shown to occur in the present work. Furthermore, porphyrin compounds are notorious for picking up copper during processing of any kind. Some of the evidence for the absence of iron in the vaccinia preparations, e.g. no inhibition of cysteine oxidation in the presence of vaccinia virus preparations when $\alpha \alpha^{\prime}$-dipyridyl was added, is evidence only for the absence of ferric iron; haem iron is in the ferrous state. The diethyldithiocarbamate test for copper could not be applied to the intact Rous virus preparations as used in the present work, for the intense brown of haem iron is as strong as the expected brown from an equivalent amount of copper with this reagent.

There may be no discrepancy in the present finding of haem iron in fowltumour virus preparations and the finding of copper in other materials which, as mentioned earlier, usually give whiter preparations. The finding of haematin implies that caution should be exercised in claiming the presence of catalase in viruses without first testing for haematin; and that in testing for iron, ferrous as well as ferric iron should be looked for.

The separation of the haemin-contaminated and ordinary Rous virus by the common method of virus purification, namely, alternating cycles of slow and fast centrifugation also suggests that the value of this process might well be reconsidered. In the experiment done in the present work, only a fraction of the original very small amount of harmless haematin was discarded by the sacrifice of half of the actual virus prepared by rather tedious and lengthy methods.

All expenses in connexion with this work were borne by the British Empire Cancer Campaign.

\section{REFERENCES}

Amies, C. R. \& CARR, J. G. (1939). Immunological experiments with highly concentrated suspensions of the Rous I tumour-producing agent. J. Path. Bact. 49, 497 .

CARr, J. G. (1953). The multiplication of the fowl tumour viruses. Symp. Soc. gen. Microbiol. 2, 284.

CARr, J. G. \& Harris, R. J. C. (1951). The preparation and assay of the Rous I sarcoma agent. Brit. J. Cancer, 5, 83. 
Cladde, A. (1941). Particulate components of cytoplasm. Cold Spr. Harb. Symp. quant. Biol. 9, 263.

Gye, W. E. \& Purdy, W. J. (1930). The Rous sarcoma No. 1 : loss of filtrate activity at incubator temperature: protection by means of hydrocyanic acid. Brit. J. exp. Path. 11, 281.

Hoagland, C. L., Ward, S. M., Smadel, J. E. \& Rivers, T. M. (1940). Constituents of elementary bodies of vaccinia. IV. Demonstration of copper in the purified virus. J. exp. Med. 76, 69.

Hoagland, C. L., Ward, S. M., Smadel, J. E. \& Rivers, T. M. (1942). Constituents of elementary bodies of vaccinia. VI. Studies on the nature of the enzymes associated with the purified virus. J. exp. Med. 76, 163.

Kreke, C. W., Bartlett, M. D. \& Smalt, M. A. (1945). Acceleration of catalase activity. J. biol. Chem. 158, 469.

Macfarlane, M. G. \& Salaman, M. H. (1940). The enzymatic activity of vaccinial elementary bodies. Brit. J. exp. Path. 19, 184.

Mueller, J. H. (1928). The effect of oxidation on filtrates of a chicken sarcoma (chicken tumor no. 1-Rous). J. exp. Med. 48, 343.

Stern, K. G. \& Duran-Reynals, F. (1939). On the nature of the agent causing sarcoma in fowls. Science, 89,609 .

Stern, K. G. \& Kirschbaum, A. (1939). On the nature of the agent causing leucosis in fowls. Science, 89,610 .

(Received 10 November 1952) 